\title{
Kondisi Brucellosis setelah Vaksinasi di Kecamatan Majauleng Kabupaten Wajo Sulawesi Selatan
}

\author{
Sulaxono Hadi ${ }^{*}$, Ratna Loventa Sulaxono ${ }^{1}$, Siswani $^{1}$ \\ ${ }^{1}$ Balai Besar Veteriner Maros \\ *Corresponding author: idahonoxalus@gmail.com
}

\begin{abstract}
Abstrak
Vaksinasi brucellosis telah dilakukan secara massal di Kabupaten Majauleng, Kabupaten Wajo, Sulawesi Selatan tahun 2013 dan 2014 menggunakan vaksin brucellosis RB51. Vaksinasi dimaksudkan untuk mengendalikan dan menekan angka prevalensi yang tinggi di Kabupaten Wajo yang mencapai angka 30\%. Surveilans telah dilakukan oleh Balai Besar Veteriner Maros untuk melihat dan mengevaluasi prevalensi brucellosis yang terjadi beberapa tahun kemudian untuk melihat penurunan prevalensi brucellosis pasca vaksinasi. Pada tahun 2016 telah dilakukan pengujian sampel serum yang berasal dari Kabupaten Wajo. Sebanyak 118 serum telah diuji dengan Rose Bengal Test (RBT) yang diteruskan dengan Complement Fixation Test (CFT). Hasilnya menunjukkan bahwa brucellosis masih ditemukan di Kabupaten Wajo dengan angka prevalensi sebesar 25,42\%. Prevalensi terbesar ditemukan di Kecamatan Takalalla yang mencapai 73,68\%, sedangkan di Kecamatan Majauleng sebesar 3.13\%. Sampling lanjutan dilakukan pada tahun 2020 di kecamatan terpadat populasi sapinya yaitu Kecamatan Majauleng. Prevalensi brucellosis pada tahun 2020 di dua desa di Kecamatan Majauleng meningkat menjadi sebesar $6 \%$.
\end{abstract}

Kata kunci: Brucellosis, Prevalensi, Uji serologis

\section{Abstract}

Brucellosis vaccination has been conducted en masse in Majauleng Subdistrict, District of Wajo, South Sulawesi in 2013 and 2014 using the RB51 brucellosis vaccine. Vaccination is intended to control and suppress the high prevalence rate in Wajo District which reaches $30 \%$. Surveillance has been conducted by the Maros Veterinary Center to look at and evaluate the prevalence of brucellosis that occurs several years later to see a decrease in the prevalence of post-vaccination Brucellosis. In 2016, serum samples were tested from District of Wajo. A total of 118 serums were tested with Rose Bengal Test (RBT) which was continued with Complement Fixation Test (CFT). The results showed that brucellosis is still found in District of Wajo with a prevalence rate of $25.42 \%$. The largest prevalence was found in Takalalla Subdistrict which reached $73.68 \%$, while in Majauleng Subdistrict it was 3.13\%. Further sampling is conducted in 2020 in the most populous district of the cow population, majauleng subdistrict. The prevalence of brucellosis in 2020 in two villages in Majauleng Sub-district increased by $6 \%$.

Keywords: Brucellosis, Prevalence, Serological test 
Prosiding Seminar Nasional Pembangunan dan Pendidikan Vokasi Pertanian

Politeknik Pembangunan Pertanian Manokwari, 31 Juli 2021

e ISSN : 2774-1982

DOI : https://doi.org/10.47687/snppvp.v2i1.169

\section{PENDAHULUAN}

Brucellosis merupakan penyakit keluron menular pada bangsa sapi (bovinae) yang disebabkan oleh kuman Brucella abortus (Anonimous, 2018). Penyakit ini menyebabkan adanya keguguran pada sapi dan kerbau betina bunting yang terserang penyakit ini.

Keguguran terutama terjadi pada kebuntingan pertama dan kedua. Peluang terjadinya keguguran makin berkurang pada kebuntingan berikutnya. Bahkan berdasarkan wawancara dengan peternak, sapi betina ada yang tetap sehat dan mampu melahirkan hingga kebuntingan ke 12 dengan kondisi induk yang baik.

Brucellosis pada sapi di Indonesia disebabkan oleh Brucella abortus strain 19. Penyakit yang menjadi perhatian utama pemerintah untuk dikendalikan ini termasuk dalam salah satu penyakit prioritas diantara 5 jenis penyakit yang ada. Kebijakan pengendalian penyakit brucellosis di Indonesia dilakukan dengan test and slaughter, melakukan pengujian pada sapi dan kerbau, bila positif maka rekator harus dipotong dalam pengawasan petugas. Daging masih bisa dijual atau dikonsumsi kecuali alat reproduksi. Kebijakan lainnya pengendalian brucellosis adalah dengan jalan vaksinasi menggunakan vaksin Brucella abortus. Kebijakan test and slaughter dilakukan bila seroprevalensi kurang dari $2 \%$ dalam populasi, tetapi bila prevalensi lebih dari $2 \%$ maka kebijakan yang diambil adalah dengan vaksinasi. Prevalensi penyakit bervariasi pada berbagai daerah di Indonesia. Prevalensi pada sapi perah yang dipelihara sebesar 4,5\% (Sudibyo, 1995).

Vaksinasi brucellosis di Indonesia dilakukan dengan vaksin brucella strain 19 atau strain RB-51. Vaksin strain 19 diproduksi oleh Pusat Veteriner Surabaya, sedangkan strain RB-51 berasal dari impor. Pemberian tanda pada sapi-sapi yang telah divaksin dengan vaksin strain 19 adalah penting untuk DIVA karena deteksi serologis yang dilakukan di Indonesia untuk surveilans brucellosis menggunakan antigen dari strain 19, sehingga seropositif untuk membedakan sapi yang tervaksin dengan terinfeksi dengan mudah dapat dilakukan. Strain Brucellosis abortus yang bisa menginfeksi sapi selain S19 dan RB51, Shetsova et al. (2016) mengidentikasi adanya S82 dan S94 pada sapi di Kazakhtan serta mengelompokkan menjadi 3 klaster, yaitu Klaster Kazakhtan-Chinese, Eropean dan American.

Surveilans dan pengujian brucellosis di Kabupaten Wajo telah dilakukan dengan maksud untuk melihat kembali keberadaan penyakit ini pada populasi sapi di kabupaten Wajo mengingat kabupaten Wajo pernah melakukan program vaksinasi massal brucellosis dengan menggunakan strain vaksin RB-51 selama 2 tahun berturut-turut, tahun 2013 dan 
Prosiding Seminar Nasional Pembangunan dan Pendidikan Vokasi Pertanian

Politeknik Pembangunan Pertanian Manokwari, 31 Juli 2021

e ISSN : 2774-1982

DOI : https://doi.org/10.47687/snppvp.v2i1.169

2014. Berdasarkan informasi petugas vaksinasi dilakukan karena tingginya angka prevalensi brucellosis di Wajo hingga mencapai angka 30\% serta banyaknya keluhan terjadinya aborsi pada sapi.

\section{METODE}

Surveilans dilakukan samping dengan risk base surveilans, pada kecamatan yang memiliki populasi sapi terbesar di kabupaten Wajo yaitu kecamatan Majauleng, yang tidak ada keluhan keguguran paska vaksinasi massal tahun 2013 dan 2014.

Uji di laboratorium serologi dilakukan dengan screening test menggunakan metode uji aglutinasi Rose Bengal Test (RBT). Antigen RBT diperoleh dari Pusat Veterinaria Farma Surabaya. Bila hasil uji dengan RBT ada yang positif yang ditandai dengan terjadinya aglutinasi pada papan uji, maka pengujian dilanjutkan dengan uji Complement Fixation Test (CFT). Bahan yang diuji berupa serum sapi sebanyak 50 sampel yang diperoleh dari 13 peternak di Desa Laeurung, Kecamatan Majauleng, Kabupaten Wajo.

\section{HASIL DAN PEMBAHASAN}

Kabupaten Wajo memiliki 14 Kecamatan dengan populasi sapi sebesar 125.050 ekor. Untuk kecamatan Majauleng populasi sapi mencapai 23.281 ekor atau 18,62\% dari populasi sapi di kabupaten Wajo. Rincian populasi sapi dan kerbau per kecamatan terdapat pada Tabel 1.

Tabel 1. Data populasi sapi dan kerbau (satuan ekor) per kecamatan di Kabupaten Wajo

\begin{tabular}{lcccccc}
\hline Kecamatan & $\begin{array}{l}\text { Sapi } \\
\text { jantan }\end{array}$ & $\begin{array}{c}\text { Sapi } \\
\text { betina }\end{array}$ & $\begin{array}{c}\text { Jumlah } \\
\text { sapi }\end{array}$ & $\begin{array}{l}\text { Kerbau } \\
\text { jantan }\end{array}$ & $\begin{array}{l}\text { Kerbau } \\
\text { betina }\end{array}$ & $\begin{array}{c}\text { Jumlah } \\
\text { kerbau }\end{array}$ \\
\hline Subbangparu & 272 & 682 & 954 & 0 & 0 & 0 \\
Tempe & 532 & 1421 & 1953 & 0 & 0 & 0 \\
Pammana & 3502 & 8817 & 12319 & 33 & 65 & 98 \\
Takalalla & 5620 & 14335 & 19955 & 9 & 20 & 29 \\
Sajoanging & 2421 & 5831 & 8232 & 37 & 71 & 108 \\
Majauleng & 6783 & 16498 & 23281 & 462 & 799 & 1261 \\
Tanasitolo & 1317 & 3341 & 4658 & 137 & 326 & 468 \\
Belawa & 608 & 1427 & 2035 & 0 & 0 & 0 \\
Maniangpajo & 1534 & 4103 & 5637 & 461 & 509 & 970 \\
Bola & 4389 & 11179 & 15568 & 189 & 334 & 532 \\
Penrang & 3759 & 9622 & 13381 & 161 & 357 & 518 \\
Gilireng & 3896 & 7236 & 11132 & 858 & 1593 & 2451 \\
Keera & 1372 & 3672 & 5044 & 52 & 61 & 113 \\
\hline \multicolumn{1}{c}{ Total } & 36244 & 88806 & 125050 & 2399 & 4135 & 6534 \\
\hline
\end{tabular}


Prosiding Seminar Nasional Pembangunan dan Pendidikan Vokasi Pertanian Politeknik Pembangunan Pertanian Manokwari, 31 Juli 2021

e ISSN : 2774-1982

DOI : https://doi.org/10.47687/snppvp.v2i1.169

Berdasarkan surveilans yang dilakukan oleh Balai Besar Veteriner Maros tahun 2016, reaktor brucellosis di kabupaten Wajo ternyata masih tinggi, dari sebanyak 118 serum yang diuji, rektor yang ditemukan sebanyak 30 sapi reaktor brucellosis atau $25,42 \%$. Khusus untuk kecamatan Majauleng, dari 32 sampel serum yang diuji tahun yang sama, ditemukan 1 sapi reaktor brucellosis atau 3,13\%. Ada beberapa faktor resiko yang menjadi kemungkinan adanya reaktor brucellosis di kabupaten Wajo, diantaranya masih belum semua peternak melakukan perkawinan sapinya dengan inseminasi buatan, adanya pembelian sapi dari daerah lain di kabupaten Wajo yang masih tertular brucelliosis, belum mengertinya peternak bahwa penyebab keguguran pada sapi betina yang bunting disebabkan oleh brucellosis dan potensi menular ke sapi lain karena adanya kontaminasi kuman, dan tidak segera dilakukan pemotongan pada sapi reaktor brucellosis. Cardenas et al. (2019) telah mengidentifikasi dan mengujur odd ratio (OD) penularan brucellosis di Columbia, daerah yang belum bebas brucellosis memiliki resiko besar dalam penyebaran brucellosis dibanding yang telah bebas dengan OD 4,84.

Berdasarkan Tabel 2, terlihat dari serum sapi yang diambil serum sebanyak 118 sampel pada tahun 2016 dan diuji brucellosis, reaktor brucellosis ditemukan di Kabupaten Wajo sebesar 25,42\% dengan prevalensi tertinggi di Kecamatan Takalalla, yang mencapai $73,68 \%$ dari 38 sampel serum yang diuji serologis. Populasi sapi di kecamatan ini mencapai 19.955 ekor, terbesar kedua setelah kecamatan Majauleng. Prevalensi Brucellosis di kecamatan Majauleng sebesar 3,13\% dari 32 sampel serum yang diuji serologis.

Tabel 2. Hasil uji serologis Brucellosis tahun 2016 sebelum program vaksinasi massal

\begin{tabular}{lccc}
\hline $\begin{array}{l}\text { Nama } \\
\text { kecamatan }\end{array}$ & $\begin{array}{l}\text { Jumlah sampel } \\
\text { positif Brucellosis }\end{array}$ & $\begin{array}{l}\text { Jumlah sampel } \\
\text { diuji Brucellosis }\end{array}$ & $\begin{array}{l}\text { Persentase } \\
(\%)\end{array}$ \\
\hline Majauleng & 1 & 32 & 3,13 \\
Pammana & 1 & 47 & 2,13 \\
Sabbang Paru & 0 & 1 & 0,00 \\
Takakalla & 28 & 38 & 73,68 \\
\hline \multicolumn{1}{c}{ Total } & 30 & 118 & 25,42 \\
\hline
\end{tabular}

Berdasarkan hasil uji serologis secara seri, RBT dan CFT tahun 2020 dari 50 sampel serum yang dari desa Paria dan desa Laeurung, kecamatan Majauleng, diketahui rekator brucellosis di kedua desa ini sebesar 6\%, dengan rincian di desa Paria 10\% dan desa Laerung 5\%. Prevalensi ini mengalami peningkatan dua kali lipat dibanding tahun 2016. Rincian hasil uji tertera pada Tabel 3. 
Prosiding Seminar Nasional Pembangunan dan Pendidikan Vokasi Pertanian

Politeknik Pembangunan Pertanian Manokwari, 31 Juli 2021

e ISSN : 2774-1982

DOI : https://doi.org/10.47687/snppvp.v2i1.169

Tabel 3. Hasil pengujian serologis brucellosis sapi dari Desa Paria dan Desa Laeurung, Kecamatan Majauleng, tahun 2020

\begin{tabular}{|c|c|c|c|}
\hline $\begin{array}{l}\text { Nama } \\
\text { desa }\end{array}$ & $\begin{array}{l}\text { Jumlah sampel } \\
\text { positif Brucellosis }\end{array}$ & $\begin{array}{l}\text { Jumlah sampel } \\
\text { diuji Brucellosis }\end{array}$ & $\begin{array}{l}\text { Persentase } \\
(\%)\end{array}$ \\
\hline Paria & 1 & 10 & 10,00 \\
\hline Laerung & 2 & 40 & 5,00 \\
\hline Total & 3 & 50 & 6,00 \\
\hline
\end{tabular}

Penandaan, pengawasan dan pemotongan sapi reaktor brucellosis adalah menjadi hal penting dalam program pengendalian brucellosis, untuk mengurangi resiko penularan dan menekan peningkatan angka prevalensi. M-Zahri-Saad et al. (2016) melihat adanya penurunan angka prevalensi brucellosis setelah dilakukan program massal pengendalian di Malaysia, Pada tahun 1979 angka prevalensi brucellosis pada sapi potong di Malaysia mencapai angka 5\%, dan dapat diturunkan hingga 0,23\% pada tahun 1988. Angka ini pada tahun 2016 naik kembali menjadi 5\% karena tidak adanya penandaan sapi reaktor brucellosis dan yang dipotong malah sapi yang bukan reaktor brucellosis.

Pengendalian brucellosis efektif untuk menurunkan angka prevalensi, Korea telah melakukan program ini tahun 2005 dan 2006 secara massal dengan maksud juga menurunkan angka prevalensinya pada manusia melalui pengendalian brucellisis pada sapi, hasilya berkorelasi positif, penurunan brucellosis pada sapi, dan terjadi penurunan angka brucellosis pada manusia (Ryu et al., 2019).

Pada angka prevlensi yang tinggi, pengendalian brucellosis bisa dilakukan dengan vaksinasi menggunakan S19 atau RB51. Vaksinasi brucellosis dengan vaksin kedua strain tersebut pada sapi umur 4-8 bulan mampu menginduksi respon kekebalan dengan ditandai adanya proliferasi CD4 dan CD8 dari sel T, IFN-gamma dan IL-17A CD4 sel T serta IL-6 IgG1. Respon kekebalan oleh vaksin S19 menunjukkan eksistensi sel memory IFN-gamma yang lebih tinggi daripada RB51 (Dorneles et al., 2015).

\section{KESIMPULAN DAN SARAN}

Brucellosis masih ditemukan di kabupaten Wajo pada tahun 2016 prevalensi yang ditemukan sebesar 25,42\%, dengan prevalensi terbesar di kecamatan Takalalla yang mencapai 73,68\%. Prevalensi brucellosis di kecamatan Majauleng mencapai angka 3,13\% pada tahun 2016. Prevalensi brucellosis pada tahun 2020 di dua desa di kecamatan Majauleng adalah sebesar $6 \%$.

Disarankan agar pemberantasan brucellosis di kabupaten Wajo hendaknya terus dilanjutkan dengan vaksinasi massal. Kombinasi dengan test and slaughter pada sapi yang 
Prosiding Seminar Nasional Pembangunan dan Pendidikan Vokasi Pertanian

Politeknik Pembangunan Pertanian Manokwari, 31 Juli 2021

e ISSN : 2774-1982

DOI : https://doi.org/10.47687/snppvp.v2i1.169

tidak tervaksin juga perlu dilakukan untuk menekan masih tingginya angka prevalensi.

Diperlukan adanya pengawasan terhadap pemindahan kepemilikan sapi reaktor brucellosis serta pengawasan petugas saat sapi reaktor akan dipotong.

\section{DAFTAR PUSTAKA}

Anonimous. (2018). Brucellosis: Brucella abortus. The Center for Food Scurity \& Public Health.

Anonimous. (2019). Chapter 6, Surveillance of bovine brucellosis. OIE, Paris.

Anonimous. (2020). Brucellosis. OIE, word organization for animal health.

Cardenas, L., Pena, M., Melo, O., \& Casal, J. (2019). Risk factor for new bovine brucellosis infec-tious in columbia herds. BMC Vet Research: 81.

Dorneles, E.M.S., Lima, G.K., Teixeira-Carvallo, A., Aranjo, M.S.S., Martins-Fitho, O.A., Sriranganathan, N., Al-Qublan, H., Hinemann, \& M.B., Lage, A.Y. (2015). Immune respons of calves vaccinated with Brucella abortus S19 or RB51 and revaccinated with RB51. Plos-ONE: 10 (9).

Kudoglu, M., Cetin, O., Kurdoglu, Z., \& Akdenoz, H. (2015). The Effect of brucellosis on women's health and reproduction. Intern. J. Of Women Health and Reprod Science, Vol. 3(4): 176-183.

Mertihan, K., Orhun, C., Zehra, K., \& Hayrettin, A. (2015). The Effect of brucellosis on women's health and reproduction. Intern. J. Of Women Health and Reprod Science, Vol. 3(4): 176-183.

Ryu, S., Ricardo, J., Magalhaes, S., \& Chul-Chun, B. (2019). The impact of expanded brucellosis surveilance in beef cattle on human brucellosis in Korea: An interuppted time-series analysis. BMC Infect Dis. 19:201.

Shetsova, E., Shevtsov, A., Mukanov, A., Filipenko, M., Kamalova, D., Sytnik, I., Syzdikov, M., Kutnetsov, A., Akhmetova, A., Zharova, M., Karibavev, T., Talokov, P., \& Ramanculov, E. (2016). Epidemiology of brucellosis and genetic diversity of Brucella abortus in Kazakhtan. Plos-ONE, 11 (12).

Tabar, H. \& Jafari, G.R.A. (2014). Prvetive and control programme for brucellosis in human and animals. A review article. J.of Zoonosis, (1)1.

Sudibyo, A. (1995). Studi epidemiologi brucellosis dan dampaknya terhadap reproduksi sapi perah di DKI Jakarta. Journal Ilmu Ternak dan Veteriner, (1)1.

Zamri-Saad, M. \& Kamaruddin, M.I. (2016). Control of animal brucellosis: The Malaysian experience. Asia Pasific J.of Trop. Med, Vol 9, 12: 1136-1140.

Sukyun, R., Ricardo, J., Soares, M., \& Byung, C. (2019). The impact of expanded brucellosis surveilance in beef cattle on human brucellosis in Korea: An interuppted time-series analysis. BMC Infect Dis. 19:201. 